University of Nebraska - Lincoln

DigitalCommons@University of Nebraska - Lincoln

Publications, Agencies and Staff of the U.S.

Department of Commerce

U.S. Department of Commerce

2012

\title{
Spatial variation in RNA:DNA ratios of Diporeia spp. in the Great Lakes region
}

Daniel J. Ryan

Purdue University

Maria S. Sepúlveda

Purdue University

Thomas F. Nalepa

National Oceanic and Atmospheric Administration, thomas.nalepa@noaa.gov

Tomas O. Höök

Purdue University, thook@purdue.edu

Follow this and additional works at: https://digitalcommons.unl.edu/usdeptcommercepub

Part of the Environmental Sciences Commons

Ryan, Daniel J.; Sepúlveda, Maria S.; Nalepa, Thomas F.; and Höök, Tomas O., "Spatial variation in RNA:DNA ratios of Diporeia spp. in the Great Lakes region" (2012). Publications, Agencies and Staff of the U.S. Department of Commerce. 407.

https://digitalcommons.unl.edu/usdeptcommercepub/407

This Article is brought to you for free and open access by the U.S. Department of Commerce at DigitalCommons@University of Nebraska - Lincoln. It has been accepted for inclusion in Publications, Agencies and Staff of the U.S. Department of Commerce by an authorized administrator of DigitalCommons@University of Nebraska - Lincoln. 


\title{
Spatial variation in RNA:DNA ratios of Diporeia spp. in the Great Lakes region
}

\author{
Daniel J. Ryan ${ }^{a}$, Maria S. Sepúlveda a , Thomas F. Nalepa ${ }^{\text {b }}$, Tomas O. Höök a,* \\ a Purdue University, Department of Forestry and Natural Resources, 715 West State Street, West Lafayette, IN 47907, USA \\ b National Oceanic and Atmospheric Association, Great Lakes Environmental Research Laboratory, 4840 S. State Road, Ann Arbor, MI 48108, USA
}

\section{A R T I C L E I N F O}

\section{Article history:}

Received 6 December 2010

Accepted 8 December 2011

Available online 23 February 2012

Communicated by David R. Barton

\section{Keywords:}

Diporeia spp.

RNA:DNA

Condition

Abundance

Dreissenids

\begin{abstract}
A B S T R A C T
Over the past two decades, Diporeia in all of the Laurentian Great Lakes, except Superior, have declined dramatically. These declines have seemingly coincided with expansion of invasive Dreissena polymorpha and $D$. bugensis, however the exact mechanisms underlying decreasing Diporeia densities are obscure. We explored the use of RNA:DNA (R/D) ratios as a conditional index for Diporeia by experimentally demonstrating that Diporeia R/D responds to periods of starvation. Moreover, during 2008-2009 we collected Diporeia from throughout the Great Lakes and Cayuga Lake (New York, USA), and used R/D ratios to index condition of these in situ collected animals. We evaluated spatial and temporal variation of nucleic acid indices using classification and regression tree (CART) analysis with a suite of environmental variables included as potential predictors. Diporeia R/D of in situ collected specimens exhibited pronounced spatial and temporal variation, but multiple CART models described only a small amount of this variation. While we observed some variation in Diporeia R/D among lakes, nucleic acid ratios appeared to respond weakly to Diporeia population characteristics and local environmental conditions. Specifically, CART analyses revealed that Diporeia R/D was particularly low at extreme depths, and interestingly, Diporeia nucleic acids were not strongly associated with the presence of dreissenids. In summary, while a limited amount of variation in Diporeia R/D was attributable to environmental conditions, the majority of Diporeia R/D variation was unaccounted for. Hence, the causative factors underlying spatio-temporal variation of Diporeia R/D and the mechanistic reasons for Diporeia declines in the Great Lakes remain largely unknown.
\end{abstract}

(c) 2012 International Association for Great Lakes Research. Published by Elsevier B.V. All rights reserved.

\section{Introduction}

A widespread ecological shift in benthic communities of the Great Lakes region has occurred within the past two decades. The once abundant, deep water genus of amphipods, Diporeia spp. (hereafter, referred to as Diporeia), has declined precipitously in lakes Erie, Huron, Michigan and Ontario. While the underlying mechanisms of Diporeia collapse are poorly understood, it is evident that Diporeia declines have resulted in a suite of ecological consequences. Diporeia is a detritivore that feeds at the sediment-water interface, and recycles pelagic and benthic nutrients to higher trophic levels (Flint, 1986; Quigley and Vanderploeg, 1991; Fitzgerald and Gardner, 1993; Nalepa et al., 2006b). In fact, declines in lipid rich Diporeia have been linked to fish malnutrition resulting in reduced overall fish growth rate, condition and delayed maturation, especially for economically important lake whitefish (Coregonus clupeaformis) (Pothoven et al., 2001; Hondorp et al., 2005; Hoyle, 2005; Pothoven, 2005; Wang et al., 2008).

Spatial patterns of Diporeia declines across the Great Lakes region are quite complex, but have been hypothesized to be influenced by

\footnotetext{
* Corresponding author. Tel.: +1 7654966799.

E-mail address: thook@purdue.edu (T.O. Höök).
}

the expansion of non-native Dreissena spp. (D. polymorpha, and in particular, D. bugensis) populations. In Lake Erie, Diporeia have been seemingly extirpated after dreissenid establishment (Dermott and Kerec, 1997). Vast areas once inhabited by Diporeia in lakes Huron, Michigan and Ontario are now devoid of the amphipod, and some extirpations have occurred in areas far removed from dreissenids (Dermott et al., 2005b; Nalepa et al., 2006b; Watkins et al., 2007). Diporeia populations in these lakes now persist in deep areas, where dreissenid impacts are thought to be low (Dermott et al., 2005b). In Lake Superior, dreissenid populations are limited to shallow productive bays (Grigorovich et al., 2003, 2008) and Diporeia populations appear to be stable (Scharold et al., 2004; Auer et al., 2009). Batchawanna Bay, Lake Superior, is noteworthy in that this relatively shallow embayment is devoid of dreissenids and has extant Diporeia populations (Dermott, 1995). However, not all Diporeia populations that coexist with dreissenids are declining. For example, Cayuga Lake, a Finger Lake in New York State, has large co-existing populations of both taxa (Dermott et al., 2005a).

Spatial variation in Diporeia condition may be affected by various environmental factors. For instance, Diporeia condition in profundal areas of the Great Lakes may be limited by the quantity and quality of organic matter inputs to extreme depths (Evans et al., 1990; Meyers and Eadie, 1993). Potentially contributing to this phenomenon, dreissenid populations upslope of Diporeia populations may 
limit diatoms from settling in deep locations (Guiguer and Barton, 2002). Location is known to influence amphipod fecundity as well as condition, especially since organic matter availability in a specific lake is largely dependent on lake trophic status (Sundelin et al., 2008). Competitive grazing between individual Diporeia may alter food availability, thereby influencing individual Diporeia condition. Lastly, seasonal variations in food availability may affect Diporeia condition given that Diporeia growth is highly dependent on spring diatom blooms (Gardner et al., 1985; Fitzgerald and Gardner, 1993).

Given the complexities of Diporeia declines, analysis of spatial variation of Diporeia condition may contribute to elucidating mechanisms underlying declines. Using a priori knowledge of extant Diporeia populations, we investigated spatial variation of nucleic acid concentrations (RNA and DNA) in Diporeia. RNA:DNA (R/D) ratios are a short-term indicator of condition and have been quantified for a variety of organisms (Buckley, 1984; Bulow, 1987; Speekmann et al., 2007; Johannsson et al., 2008; MacLean et al., 2008), including Diporeia (Kainz et al., 2010). Within a cell, RNA is transcribed to initiate protein synthesis while DNA concentrations remain fairly constant (Bulow, 1987; Dahlberg, 1989). Thus, relatively high R/D values indicate an actively growing organism while low ratios are indicative of an organism exhibiting little growth. Past studies on a variety of organisms have indicated that nucleic acid ratios respond to organism size as well as multiple environmental factors, such as temperature and food availability (Buckley et al., 1984; Wagner et al., 2001; Johannsson et al., 2008; Schlechtriem et al., 2008). Ontogenic variation in DNA concentrations of invertebrates could imply that whole body RNA concentrations are more sensitive indices of condition than R/D (e.g., Gorokhova, 2003; Holmborn et al. 2009). However, Ryan (2010) quantified both total RNA content and R/D ratios of experimental and in situ collected Diporeia, and found that these two indices revealed very similar patterns. Moreover, Kainz et al. (2010) recently determined that Diporeia R/D ratios respond to food quality, thereby providing precedence for the use of R/D ratios to assess Diporeia condition.

While studies of diverse taxonomic groups demonstrate that nucleic acid ratios respond to various environmental factors (e.g., food, temperature) and index short-term growth (Buckley et al.,
1984; Bulow, 1987; Clemmesen, 1994; Wagner et al., 1998; Vrede et al., 2002; Schlechtriem et al., 2008), only a limited number of studies have explored the response of R/D ratios to such factors in amphipods, including Diporeia (Sutcliffe, 1965; Wu and Or, 2005; Kainz et al., 2010). We conducted experiments to independently evaluate the usefulness of RNA:DNA as an index for Diporeia condition. Moreover, we examined the variability of R/D ratios in Diporeia collected across the Great Lakes region and over different temporal periods (years, seasons). We hypothesized that 1) Diporeia R/D values would respond negatively to periods of starvation during experimentation and 2) R/D values of in situ collected Diporeia would be relatively high during spring and in shallow water areas, and be relatively low in areas where dreissenids and Diporeia co-exist.

\section{Methods}

\section{Diporeia collections}

During spring, summer and fall of 2008 and 2009, Diporeia were collected from multiple sites in lakes Huron, Michigan, Ontario, Superior and Cayuga (New York, USA) (Fig. 1 and Supplemental Table 1). Sites in the Great Lakes were the same as those routinely monitored by the Environmental Protection Agency-Great Lakes National Program Office (EPA-GLNPO), or those within the benthic monitoring program of the National Oceanic and Atmospheric Association-Great Lakes Environmental Research Laboratory (NOAA-GLERL) (Nalepa et al. 2006a). Within both monitoring programs, sites were selected primarily based on historical Diporeia abundances and secondarily based on dreissenid presence or absence. Moreover, the number of Diporeia present and weather conditions at the time of collection were limiting factors in determining which sites were sampled.

Diporeia were collected from the Great Lakes with a Ponar grab $(0.23 \times 0.23 \mathrm{~m}$ opening with $500 \mu \mathrm{m}$ mesh $)$ and from Cayuga Lake with a Petite Ponar grab $(0.15 \times 0.15 \mathrm{~m}$ opening with $500 \mu \mathrm{m}$ mesh $)$. Time permitting, up to 3 grabs were washed through a $500 \mu \mathrm{m}$ screen and retained material was preserved in $10 \%$ formalin containing rose bengal stain. These samples were used to estimate abundances of

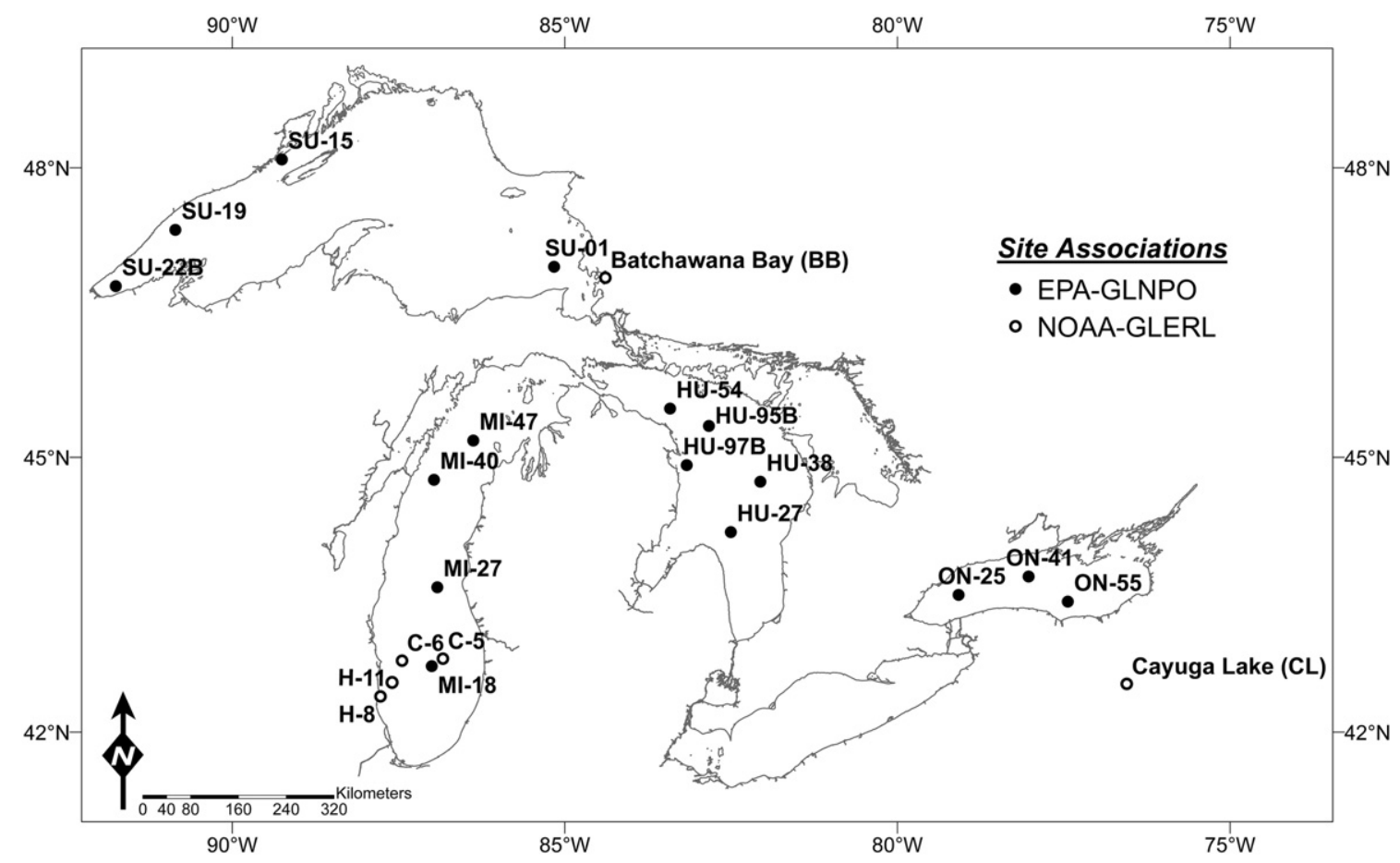

Fig. 1. Benthic sites in the Great Lakes region sampled during 2008 and 2009. Closed and open circles depict EPA-GLNPO and NOAA-GLERL sites, respectively. 
Diporeia and dreissenids. In the laboratory, Diporeia and dreissenids in these formalin preserved samples were sorted in glass pans under a magnification lens $(1.5 \times)$ and invertebrate densities were determined as no. $/ \mathrm{m}^{2}$. D. polymorpha co-occurred with $D$. bugensis in some samples, but comprised at most $2 \%$ of dreissenids collected at any location, hence these data were combined as total dreissenid density.

Animals for a starvation experiment were collected on day of year (DOY) 270, 2009 from site C-6 in Lake Michigan (Fig. 1). This site was chosen because it had relatively high densities of Diporeia based on previous sampling and was relatively proximate to our laboratory. Upon collection, Diporeia were gently removed from benthic samples and placed in containers with $4{ }^{\circ} \mathrm{C}$ lake water. In addition, a subset $(\mathrm{n}=42)$ of Diporeia was immediately preserved in $1.0 \mathrm{~mL}$ of RNAlater ${ }^{\circledR}$ to compare in situ R/D values to experimental R/D values. Containers were kept at $4{ }^{\circ} \mathrm{C}$ in the dark and transported to Purdue University (West Lafayette, IN), where they were held overnight (darkness, $4{ }^{\circ} \mathrm{C}$ ) prior to the start of the experiment.

In addition, extra Ponar grabs were taken at each site to obtain in situ Diporeia samples for RNA and DNA quantification. Upon collection, live animals were gently screened from the sediments and individuals immediately placed in vials with $1.0 \mathrm{~mL}$ RNAlater ${ }^{\circ}$, a supersaturated salt solution that preserves nucleic acids. Several past studies have successfully relied on RNAlater $®$ to preserve nucleic acids of various experimental and in situ collected animals (Gorokhova and Kyle, 2002; Gorokhova, 2003; Johnson et al., 2003; Höök et al., 2008).

\section{Starvation experiment}

Before the start of the experiment, a subset of Diporeia was preserved in RNAlater ${ }^{\circledR}(n=29)$ to quantify baseline, pre-experiment nucleic acid concentrations after animals were exposed to potential stressors associated with collection and transport to the laboratory. Remaining Diporeia $(\mathrm{n}=125)$ were placed individually into mesocosms that were constructed with $125 \mathrm{~mL}$ Erlenmeyer flasks. Each flask contained approximately $85 \mathrm{~g}$ of sieved and autoclaved Lake Michigan sand as a substrate for burrowing, $75 \mathrm{~mL}$ of Lake Michigan water collected at a depth of $100 \mathrm{~m}$ and one Diporeia. Flasks were kept in darkness at $4{ }^{\circ} \mathrm{C}$ inside a walk-in cooler. After 15 experimental days, water in flasks was exchanged by decanting approximately half the original volume and refilling with new Lake Michigan water. Random samples of 40 Diporeia were removed on days 3, 15 and 30 from the start of the experiment ( 5 additional experimental animals were allotted to account for losses due to mortality). Live Diporeia were immediately preserved in $1.5 \mathrm{~mL}$ microcentrifuge vials containing $1.0 \mathrm{~mL}$ of RNAlater ${ }^{\circledR}$, and stored at $4{ }^{\circ} \mathrm{C}$ (Gorokhova, 2005). Equipment used was routinely cleaned with RNase-OFFTM to prevent contamination of samples.

\section{Determination of nucleic acids}

Individuals from the starvation experiment and individuals preserved immediately in the field were removed from RNAlater ${ }^{\circledR}$, suspended laterally in RNase and DNase free water, lengths measured as described previously and adjusted for preservation effects (Abramoff et al., 2004; Foley et al., 2010). Forceps and Petri dishes used in length measurements were routinely cleaned with RNaseOFF $^{\mathrm{TM}}$ to prevent contamination.

After length measurements, Diporeia were placed in $1.0 \mathrm{~mL}$ of extraction buffer for extraction of nucleic acids. Whole Diporeia were homogenized mechanically with five grinding motions from an RNAase free pestle, followed by a triplicate sequence of 30 second ultrasonic treatment (Cole-Parmer, model\# 08849-00) and $1 \mathrm{~min}$ intermittent ice bath. Samples were then placed on an orbital shaker for $2 \mathrm{~h}$. Approximately $1 \%$ of the organisms' nucleic acids were removed for fluorometric determination (2 subsamples at $5 \mu \mathrm{L} /$ subsample). RNA and DNA standards and negative controls were prepared and analyzed in duplicate, concurrent with duplicate Diporeia samples. Samples were placed in a 96-well, bottom rounded microplate (Costar 3915), $70 \mu \mathrm{L}$ of the fluorophore RiboGreen ${ }^{\circledR}$ was added to all wells and total fluorescence was measured in a FLx800 multi-detection microplate reader (BioTek Instruments, Inc.). Then, $5 \mu \mathrm{L}$ of endoribonuclease RNase was added to all wells, samples were incubated at approximately $37.5^{\circ} \mathrm{C}$ for $30 \mathrm{~min}$ (temperature corresponding to maximum RNase enzyme efficiency) and total fluorescence was again measured. Gen5 ${ }^{\mathrm{TM}}$ (BioTek Instruments, Inc.) microplate data collection and analysis software was used to quantify total sample fluorescence. RNA and DNA concentrations were estimated through comparison with standard curve fluorescence and RNA and DNA ( $\mu \mathrm{g} /$ Diporeia) and R/D ratios were determined. We standardized all experimental and in situ collected samples to the mean standard curve slope ratio (2.44) (Berdalet et al., 2005; Caldarone et al., 2006). For specific reagents and reagent dilutions see Ryan (2010).

\section{Data analysis: starvation experiment}

Since individuals of different sizes were used in the starvation experiment, we evaluated allometric effects on nucleic acid expression as appropriate and accounted for size effects. To this end, linear regressions were used to determine if R/D ratios varied significantly with Diporeia length. If this relationship was not significant, an analysis of variance (ANOVA) and Tukey post-hoc test were used to compare between in situ specimens, day 0, day 3, day 15 and day 30 treatments. All statistical analyses were performed in SPSS software (version 16.0.2) and significance evaluated at $\alpha=0.05$.

\section{Data analysis: in situ collected Diporeia}

Given that the nucleic acid patterns of Diporeia likely respond to a suite of factors, with a priori undefined relationships, we used classification and regression tree analysis (CART) as an exploratory statistical approach to evaluate spatial, temporal, environmental and density effects on Diporeia nucleic acid patterns. Analysis of spatio-temporally variable environmental data can be complicated, given the potential absence of a priori model structure and complexities associated with both continuous and categorical predictive data. CART analysis is a simple, easily interpretable and increasingly used non-parametric statistical technique (Breiman et al., 1984; Lamon and Stow, 1999; Rejwan et al., 1999; De'ath and Fabricius,

Table 1

Variables used in classification and regression tree analyses to model Diporeia RNA: DNA (R/D) ratios. Pooled agency models represent spring and summer data combined from EPA-GLNPO and NOAA-GLERL sites, while NOAA-GLERL models include data from NOAA-GLERL sites collected during spring, summer and fall. Abundance was averaged over the spring and summer for pooled agency models, but not averaged for NOAAGLERL models. $\mathrm{C}=$ categorical data, $\mathrm{N}=$ continuous data.

\begin{tabular}{lll}
\hline Variables & Type & Values \\
\hline \multicolumn{2}{l}{ Pooled data models } & \\
Season & $\mathrm{C}$ & Spring, summer \\
Lake & $\mathrm{C}$ & Huron, Michigan, Ontario, Superior, Cayuga \\
Dreissena & $\mathrm{C}$ & False (absent), true (present) \\
Depth & $\mathrm{N}$ & Depth $(\mathrm{m})$ \\
Length & $\mathrm{N}$ & $>3 \mathrm{~mm}$ \\
Abundance & $\mathrm{N}$ & Mean $\left(\right.$ no./ $\mathrm{m}^{2}$ ) for spring or spring and summer collections \\
& & \\
NOAA-GLERL models & \\
Season & $\mathrm{C}$ & Spring, summer, fall \\
Lake & $\mathrm{C}$ & Cayuga, Michigan, Superior \\
Dreissena & $\mathrm{C}$ & False $(\mathrm{absent})$, true (present) \\
Depth & $\mathrm{N}$ & Depth (m) \\
Length & $\mathrm{N}$ & $>3 \mathrm{~mm}$ \\
Abundance & $\mathrm{N}$ & No./ $\mathrm{m}^{2}$ \\
\hline
\end{tabular}


Table 2

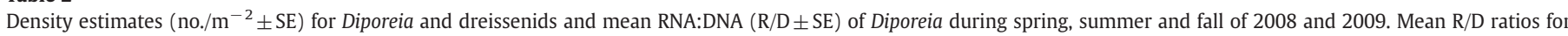

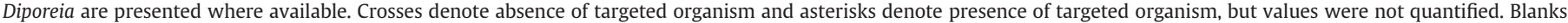
indicate that the site was not sampled during a time period.

\begin{tabular}{|c|c|c|c|c|c|c|c|}
\hline \multirow[t]{2}{*}{ Lake/Site } & \multirow[t]{2}{*}{ Season } & \multicolumn{3}{|l|}{2008} & \multicolumn{3}{|l|}{2009} \\
\hline & & $\begin{array}{l}\text { Diporeia density } \\
\left(\text { No. } / \mathrm{m}^{2}\right)\end{array}$ & $\begin{array}{l}\text { Dreissena spp. } \\
\left.\text { density (No./ } \mathrm{m}^{2}\right)\end{array}$ & $\begin{array}{l}\text { Average Diporeia } \\
\text { RNA:DNA }\end{array}$ & $\begin{array}{l}\text { Diporeia density } \\
\left(\text { No. } / \mathrm{m}^{2}\right)\end{array}$ & $\begin{array}{l}\text { Dreissena spp. } \\
\text { density (No./m²) }\end{array}$ & $\begin{array}{l}\text { Average Diporeia } \\
\text { RNA:DNA }\end{array}$ \\
\hline \multicolumn{8}{|c|}{ Cayuga Lake } \\
\hline \multirow[t]{3}{*}{$\mathrm{CL}$} & Spring & $2112 \pm 734$ & $17,398 \pm 7171$ & $0.68 \pm 0.06$ & $3477 \pm 1562$ & $11,580 \pm 1011$ & $0.57 \pm 0.03$ \\
\hline & Summer & $3764 \pm 899$ & $14,726 \pm 5290$ & $0.38 \pm 0.05$ & $2428 \pm 517$ & $10,761 \pm 1628$ & $0.62 \pm 0.03$ \\
\hline & Fall & 3534 & $*$ & $0.34 \pm 0.03$ & $6997 \pm 791$ & $11,321 \pm 4844$ & $0.84 \pm 0.07$ \\
\hline \multicolumn{8}{|c|}{ Lake Huron } \\
\hline \multirow[t]{2}{*}{ HU-27 } & Spring & $\dagger$ & $\dagger$ & $\dagger$ & & & \\
\hline & Summer & $\dagger$ & $\dagger$ & $\dagger$ & & & \\
\hline \multirow[t]{2}{*}{ HU-38 } & Spring & $*$ & $\dagger$ & $*$ & $149 \pm 21$ & $\dagger$ & $0.58 \pm 0.03$ \\
\hline & Summer & $*$ & $\dagger$ & $*$ & $*$ & $\dagger$ & $0.66 \pm 0.05$ \\
\hline \multirow[t]{2}{*}{ HU-54 } & Spring & $979 \pm 128$ & $*$ & $0.7 \pm 0.06$ & $*$ & $*$ & $0.51 \pm 0.03$ \\
\hline & Summer & $*$ & $*$ & $0.33 \pm 0.03$ & * & $*$ & $0.73 \pm 0.04$ \\
\hline HU-95B & Summer & $*$ & $\dagger$ & $*$ & $*$ & $\dagger$ & $*$ \\
\hline HU-97B & Spring & $\dagger$ & $\dagger$ & $\dagger$ & & & \\
\hline \multicolumn{8}{|c|}{ Lake Michigan } \\
\hline \multirow[t]{2}{*}{ MI-18 } & Spring & $340 \pm 191$ & $\dagger$ & $0.3 \pm 0.05$ & $787 \pm 21$ & $\dagger$ & $0.93 \pm 0.03$ \\
\hline & Summer & $*$ & $\dagger$ & $0.15 \pm 0.02$ & $*$ & $\dagger$ & $0.33 \pm 0.03$ \\
\hline MI-27 & Summer & $\dagger$ & $*$ & $\dagger$ & & & \\
\hline \multirow[t]{2}{*}{ MI-40 } & Spring & 128 & $\dagger$ & $0.78 \pm 0.11$ & $383 \pm 319$ & $\dagger$ & $0.47 \pm 0.04$ \\
\hline & Summer & $*$ & $*$ & $*$ & $*$ & $\dagger$ & $0.75 \pm 0.03$ \\
\hline MI-47 & Summer & $*$ & $\dagger$ & $*$ & & & \\
\hline \multirow[t]{3}{*}{$C-5$} & Spring & $745 \pm 43$ & $\dagger$ & $0.42 \pm 0.04$ & $149 \pm 33$ & $*$ & $*$ \\
\hline & Summer & $766 \pm 21$ & $*$ & $0.48 \pm 0.04$ & & & \\
\hline & Fall & $*$ & $\dagger$ & $0.69 \pm 0.04$ & & & \\
\hline \multirow[t]{3}{*}{ C-6 } & Spring & & & & $1007 \pm 63$ & $*$ & $0.97 \pm 0.09$ \\
\hline & Summer & & & & $931 \pm 84$ & 1064 & $0.76 \pm 0.05$ \\
\hline & Fall & & & & $601 \pm 92$ & 1596 & $0.96 \pm 0.07$ \\
\hline $\mathrm{H}-8$ & Spring & $\dagger$ & $\dagger$ & $\dagger$ & & & \\
\hline \multirow[t]{2}{*}{$\mathrm{H}-11$} & Spring & $610 \pm 138$ & $4631 \pm 2115$ & $0.42 \pm 0.04$ & $816 \pm 156$ & $\dagger$ & \\
\hline & Summer & $1287 \pm 117$ & $138 \pm 96$ & $0.43 \pm 0.03$ & $723 \pm 140$ & 362 & $0.69 \pm 0.05$ \\
\hline \multicolumn{8}{|c|}{ Lake Ontario } \\
\hline \multirow[t]{2}{*}{ ON-25 } & Spring & $223 \pm 32$ & $*$ & $0.38 \pm 0.11$ & $378 \pm 147$ & 234 & $0.98 \pm 0.09$ \\
\hline & Summer & $*$ & $\dagger$ & $*$ & $223 \pm 53$ & $\dagger$ & $0.6 \pm 0.02$ \\
\hline \multirow[t]{2}{*}{ ON-41 } & Spring & $638 \pm 85$ & $*$ & $0.49 \pm 0.07$ & 128 & $*$ & $0.57 \pm 0.05$ \\
\hline & Summer & $*$ & $\dagger$ & $0.34 \pm 0.03$ & $*$ & $*$ & $0.91 \pm 0.07$ \\
\hline \multirow[t]{2}{*}{ ON-55 } & Spring & $521 \pm 181$ & $*$ & $0.31 \pm 0.05$ & $*$ & $*$ & $0.44 \pm 0.03$ \\
\hline & Summer & $*$ & $\dagger$ & $0.34 \pm 0.03$ & $*$ & $*$ & $0.54 \pm 0.12$ \\
\hline \multicolumn{8}{|c|}{ Lake Superior } \\
\hline \multirow[t]{2}{*}{ SU-01 } & Spring & $596 \pm 43$ & $\dagger$ & $0.43 \pm 0.04$ & $628 \pm 11$ & $\dagger$ & $0.52 \pm 0.04$ \\
\hline & Summer & $*$ & $\dagger$ & $0.49 \pm 0.04$ & $*$ & $\dagger$ & $0.39 \pm 0.04$ \\
\hline SU-15 & Spring & $755 \pm 287$ & $\dagger$ & $0.19 \pm 0.05$ & $*$ & $\dagger$ & $0.92 \pm 0.28$ \\
\hline SU-19 & Spring & & & & $53 \pm 11$ & $\dagger$ & $0.56 \pm 0.05$ \\
\hline SU-22B & Summer & $*$ & $\dagger$ & $0.55 \pm 0.06$ & $*$ & $\dagger$ & $0.76 \pm 0.07$ \\
\hline $\mathrm{BB}$ & Spring & $213 \pm 86$ & $\dagger$ & $0.47 \pm 0.06$ & $206 \pm 58$ & $\dagger$ & $0.86 \pm 0.04$ \\
\hline & Summer & $333 \pm 28$ & $\dagger$ & $1.03 \pm 0.19$ & $369 \pm 47$ & $\dagger$ & $0.75 \pm 0.04$ \\
\hline & Fall & $596 \pm 81$ & $\dagger$ & $0.26 \pm 0.05$ & $369 \pm 38$ & $\dagger$ & $1.08 \pm 0.05$ \\
\hline
\end{tabular}

2000). CART is advantageous over other multivariate techniques because it can use both categorical and numerical data to construct models, identify complex relationships and is an exploratory statistical technique used to facilitate understanding of complex ecological data (Breiman et al., 1984; Faraway, 2006). In short, the CART algorithm constructs a decision tree or dendogram by iteratively splitting the dataset based on predictor variables in order to minimize the within group variation of the response variable (Breiman et al., 1984; Faraway, 2006; Qian, 2010). Regression trees (Therneau et al., 2010) and corresponding boxplots of each terminal node were constructed in the statistical package $\mathrm{R}$ ( $\mathrm{R}$ Development Core Team, 2009).

Data were excluded prior to performing CART to balance the statistical design. For instance, Diporeia abundances were low at some sites, and thus, only sites with $\mathrm{n} \geq 18$ Diporeia per sampling event were included (see Supplemental Table 1 for sites used in specific models). Further, the length of Diporeia is known to be an indicator of ontogenic stage. Diporeia considered to be young of year (approximately $\leq 3 \mathrm{~mm}$ ) were sampled inconsistently and excluded from regression trees (Winnell and White, 1984; Johnson, 1988; Nalepa et al., 2006a; Auer et al., 2009). Remaining data were evaluated for length effects using linear regression to verify that R/D ratios did not trend with Diporeia size. Four separate CART analyses were conducted, first by year (2008 and 2009) and then by agency within each year (EPAGLNPO and NOAA-GLERL). Data were initially divided by year because sample sites varied between years, and Diporeia collected in 2008 were in RNAlater@ longer than their 2009 counterparts, potentially leading to varying amounts of Diporeia nucleic acids between years (Gorokhova, 2005). Next, data were divided by agency because some sites were sampled three times per year (NOAA-GLERL sites sampled spring, summer and fall, Table 1 and Supplemental Table 1), while other sites were only sampled twice per year (EPA- 
GLNPO sites sampled spring and summer; Table 1 and Supplemental Table 1). Thus, yearly and agency samples were analyzed independently. While initial analyses did not reveal a linear association between Diporeia length and R/D ratios, organism length was nonetheless included as a potential explanatory variable to evaluate non-linear and higher order effects (i.e., effects of length after accounting for influence of other explanatory variables). See Table 1 for a complete list of explanatory variables included in CART analyses.

The regression tree algorithm constructs a dendogram by iteratively partitioning dependent variable data into two groups (or nodes), whereby within group residual sum of squares for the response variable is minimized. Due to the hierarchical structure of the dendogram, initial splits generally lead to the greatest reductions in variation. For each analysis, an overly large tree was developed, reduced in size (i.e., model pruning) through 10-fold cross-validation and this process repeated 100 times to build a distribution of trees where the modal tree was assumed to be a typical tree (De'ath and Fabricius, 2000). Selection of a conservative tree size was implemented by choosing the number of splits corresponding to the largest standard error within one standard error of the minimum crossvalidation relative error (Breiman et al., 1984; De'ath and Fabricius, 2000; Faraway, 2006; Qian, 2010).

\section{Results and discussion}

\section{Diporeia collections}

During 2008 and 2009, densities of Diporeia and dreissenids were consistently higher in Cayuga Lake than other locations (Cayuga Lake total mean densities: $3719 / \mathrm{m}^{2}$ ) (Table 2), while Diporeia densities at other sample sites varied widely (range of total mean densities from other locations: $0 / \mathrm{m}^{2}-979 / \mathrm{m}^{2}$ ) (Table 2 ). Recent investigations indicate wide spatial variation in Diporeia abundances within and among the lakes investigated. Studies in lakes Huron, Michigan and Ontario have documented substantially reduced populations or complete absences of Diporeia (Dermott, 2001; Nalepa et al., 2006b, 2007, 2009), while collections in Lake Superior suggest that Diporeia remain stable (Scharold et al., 2004; Dermott et al., 2005a; Auer et al., 2009). In addition, densities of Diporeia in Cayuga Lake have remained high despite coexistence with prolific populations of dreissenids (Dermott et al., 2005a). Our density estimates presented herein provide an additional, updated assessment of Diporeia abundances in the Great Lakes region that are generally consistent with past descriptions.

\section{Starvation experiment}

Diporeia in the 3, 15 and 30 day treatments experienced high survival (80\%), and we quantified nucleic acids for a large number of individuals (total: $n=100 ; 3 d: n=31,15 d: n=34,30 d: n=35$ ). RNA and DNA for Diporeia exhibited significant relationships with individual length (RNA: $p<0.0001$, DNA: $p<0.001$, Fig. 2a) while R/D ratios did not ( $p=0.34$, Fig. $2 b)$. We statistically compared $R / D$ ratios of in situ preserved, transported (day 0) and starved (days 3, 15 and 30) Diporeia. The R/D ANOVA with Tukey post-hoc test suggested that the in situ specimens and 30 day treatment had a significantly higher and lower mean R/D ratio, respectively, than the 0,3 and 15 day treatments $\left(F_{3,125}=14.51, \mathrm{p}<0.001\right.$, Fig. 3$)$.

The starvation experiment was designed to independently evaluate $\mathrm{R} / \mathrm{D}$ as an index for Diporeia condition by eliciting changes in Diporeia nucleic acids. Through this experiment, we observed a reduction in Diporeia R/D collected in situ and after a 30 day starvation period as expected. In addition, Ryan (2010) conducted various experiments manipulating feeding regime and temperature to examine the response of Diporeia nucleic acids. The experimental factors evaluated by Ryan (2010) in the laboratory did not always induce a shortterm response in nucleic acid ratios. Slow metabolic rates at low

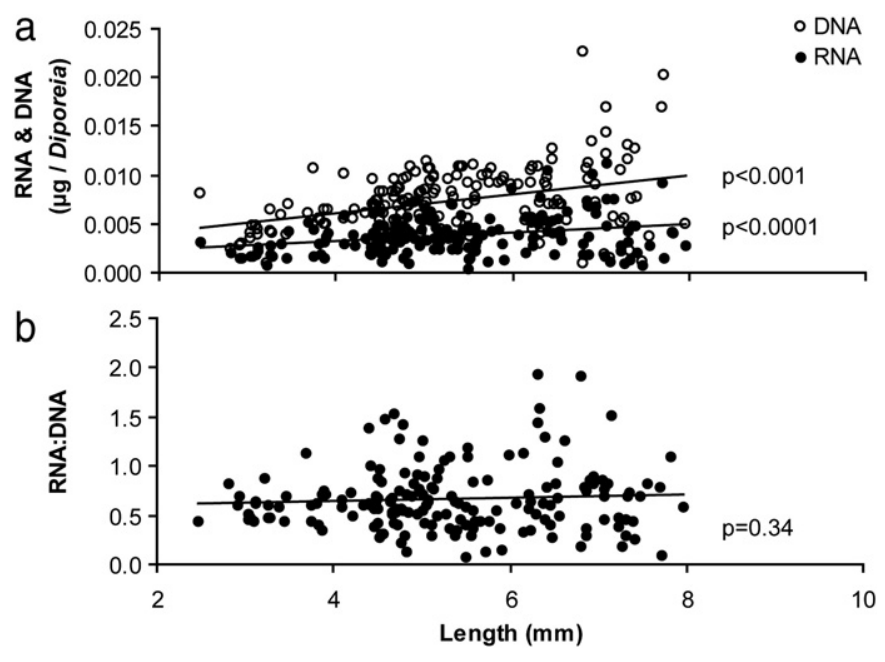

Fig. 2. Diporeia (a) RNA and DNA, and (b) RNA:DNA regressions with length from an experiment evaluating starvation effects.

temperatures likely delay the response of Diporeia to stressors, and ingestion of exuvia in the absence of food could delay starvation (Schlechtriem et al., 2008). Diporeia are known to feed intermittently and can seemingly endure periods of starvation (Quigley, 1988; Dermott and Corning, 1988, Gauvin et al. 1989, Evans et al., 1990), thus a relatively undisturbed 30 day duration of starvation may not be long enough to elicit large changes in Diporeia R/D. Moreover, Diporeia nucleic acid ratios are very low compared to other invertebrates (Wright and Hetzel, 1985; Chicharo and Chicharo, 1995; Schlechtriem et al., 2008). Kainz et al. (2010) found similar R/D values for Diporeia, however, Kainz et al.'s (2010) values are not directly comparable to our study without correcting for different standard curve slope ratios (Berdalet et al., 2005; Caldarone et al., 2006). Nonetheless, while it is not completely clear why Diporeia R/D values are extremely low in comparison to other invertebrates, these low ratios likely lead to reduced overall variation and could limit the ability to describe spatial patterns through CART analyses.

Diporeia nucleic acid ratios appear to be affected by severe short term stresses such as collection and transportation procedures. We observed a reduction of Diporeia R/D from collection in Lake Michigan to the start of experiments two days later (experimental day 0). Ryan (2010) observed similar short term reductions in R/D values during two other transportation events. Reduced Diporeia R/D ratios incurred through collection and transportation demonstrate that these indices respond to severe short term stresses (e.g., changes in pressure, temperature and cessation of feeding). Moreover, this finding has implications for other researchers when they aim to interpret results from laboratory trials with field collected Diporeia.

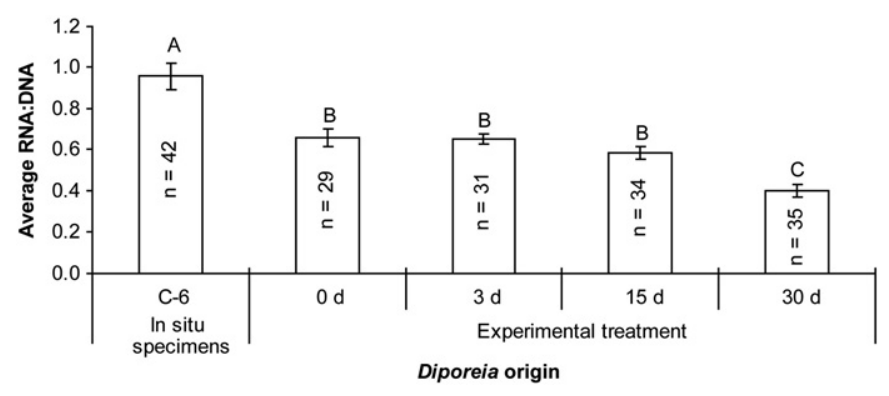

Fig. 3. Mean Diporeia RNA:DNA (R/D) for in situ preserved specimens and individuals starved for $0,3,15$ and 30 days. Shared letters denote treatments without significant differences according to a Tukey post-hoc test and error bars depict standard errors. 


\section{In situ collected Diporeia}

Diporeia R/D varied among collection sites and across seasons (Table 2). The greatest mean $\mathrm{R} / \mathrm{D}, 0.89$, was observed at site $\mathrm{C}-6$ in Lake Michigan and the lowest mean R/D, 0.41, was observed at site ON-55 in Lake Ontario (intra-assay coefficient of variation: 0.097). Over the range of lengths evaluated with linear regression, we did not find any significant linear relationships between Diporeia R/D and individual organism length (Supplemental Fig. 1a-d). Nonetheless, we conservatively included individual length as a predictive variable in CART models to account for any higher order and non-linear relationship between Diporeia length and R/D.

Collectively, CART models explained a low amount of variation in Diporeia R/D. The regression trees developed using spring and summer R/D ratios for pooled models in 2008 and 2009 were depicted with one and seven splits, respectively (Fig. 4a-d). During 2008, depth was selected as the only predictive variable and explained a low amount of variation $\left(R^{2}=0.07, p<0.0001\right)$, while in 2009, depth and lake were selected as first and second splits and the model explained a greater amount of variation $\left(R^{2}=0.19\right.$, $\mathrm{p}<0.0001$ ). Diporeia R/D from NOAA-GLERL sites during 2008 and
2009 were described with three and five splits, respectively (Fig. 5a-d). Initial splits for 2008 R/D data were based on abundance and season $\left(R^{2}=0.11, p<0.0001\right)$, with initial splits for 2009 based on season and lake $\left(\mathrm{R}^{2}=0.18, \mathrm{p}<0.0001\right)$. In the trees presented, the length of the vertical branches represents the variation explained by a split (Faraway, 2006; Qian, 2010).

Our measures of condition from in situ collected Diporeia were highly variable across space and time. Season, Diporeia length, abundance and depth (in decreasing order of appearance) appeared in CART analyses suggesting that these variables have minor influence on Diporeia condition. Diporeia condition would be expected to respond to spring diatom blooms, a historically important energy source (Gardner et al., 1985; Dermott and Corning, 1988; Quigley and Vanderploeg, 1991; Fitzgerald and Gardner, 1993). Nucleic acid indices varied seasonally, but spring peaks in Diporeia condition were not consistently reflected in dendograms. Diporeia length was selected in two dendograms as a higher order effect. The effect of length was both positive and negative, suggesting complex higher order, interactive effects of length. Abundance frequently appeared in regression trees, but effects of abundance on nucleic acid indices were not consistent. Low abundances could relate to 1) high Diporeia a

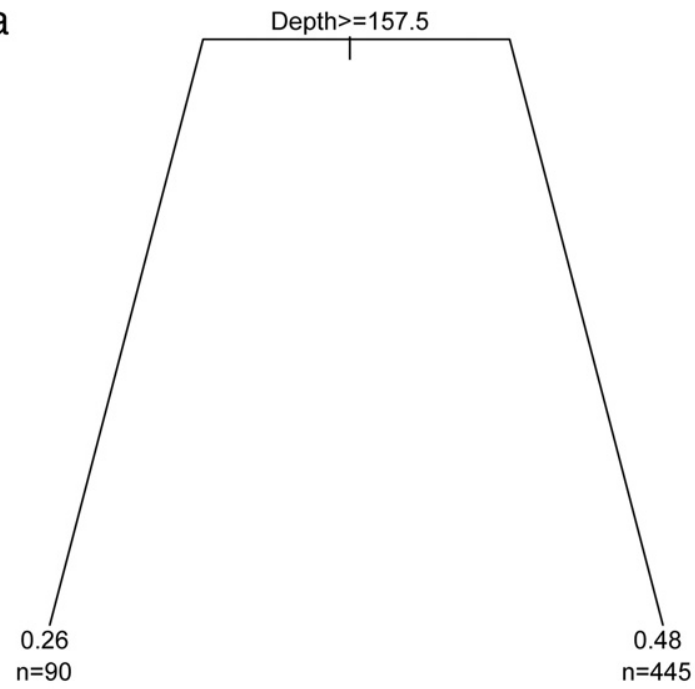

C

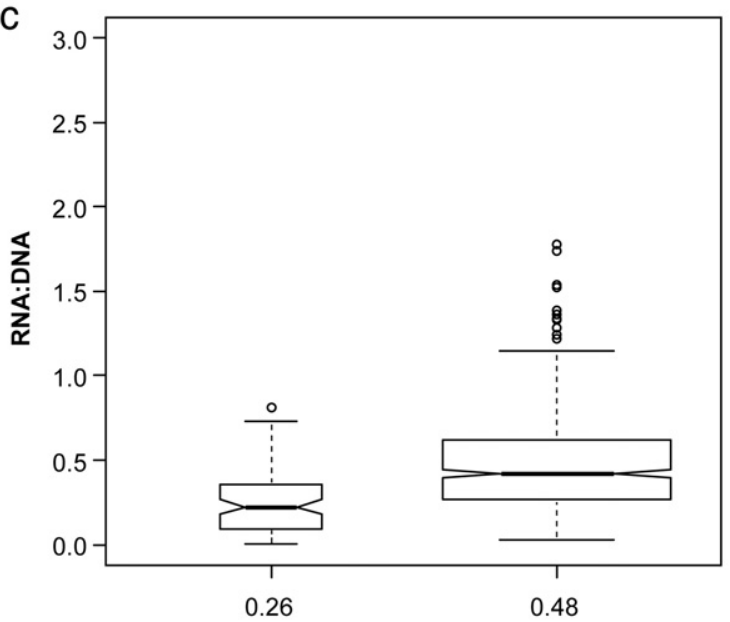

Mean RNA:DNA at terminal node

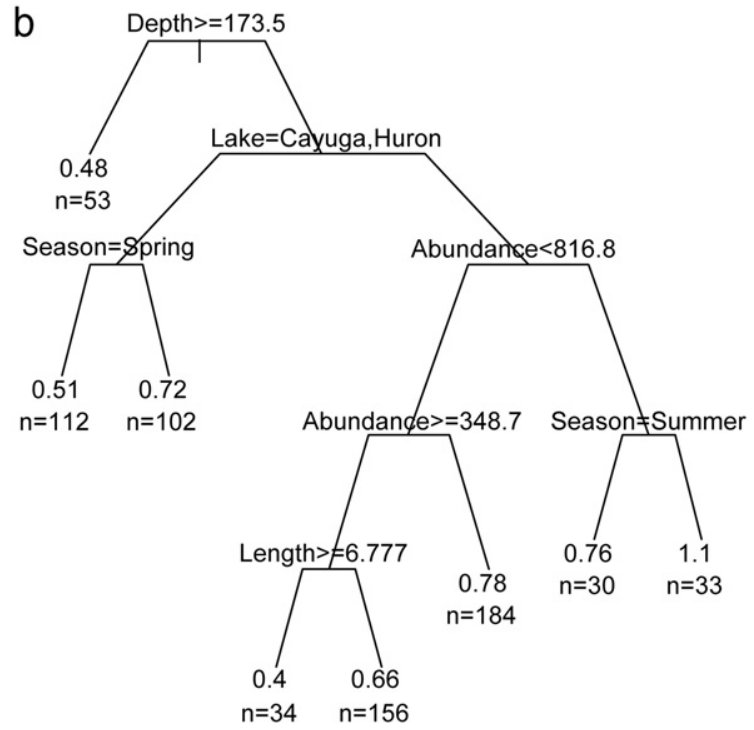

d

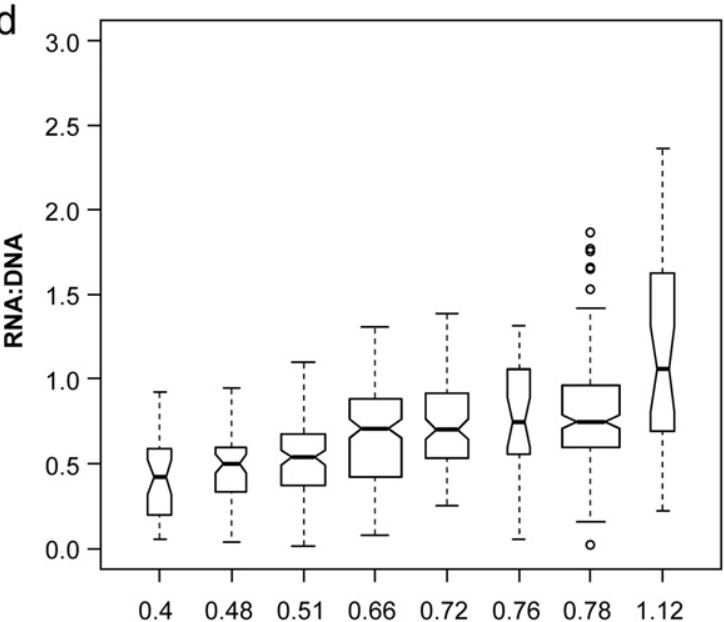

Mean RNA:DNA at terminal node

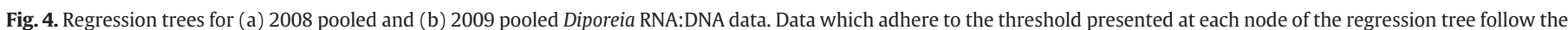

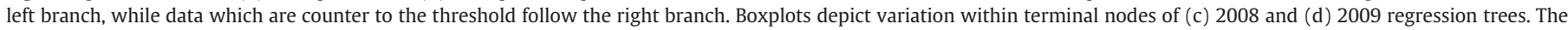

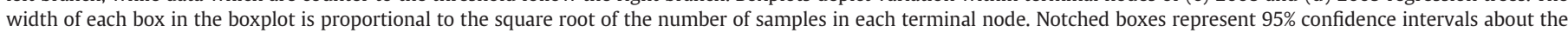
median. 
a
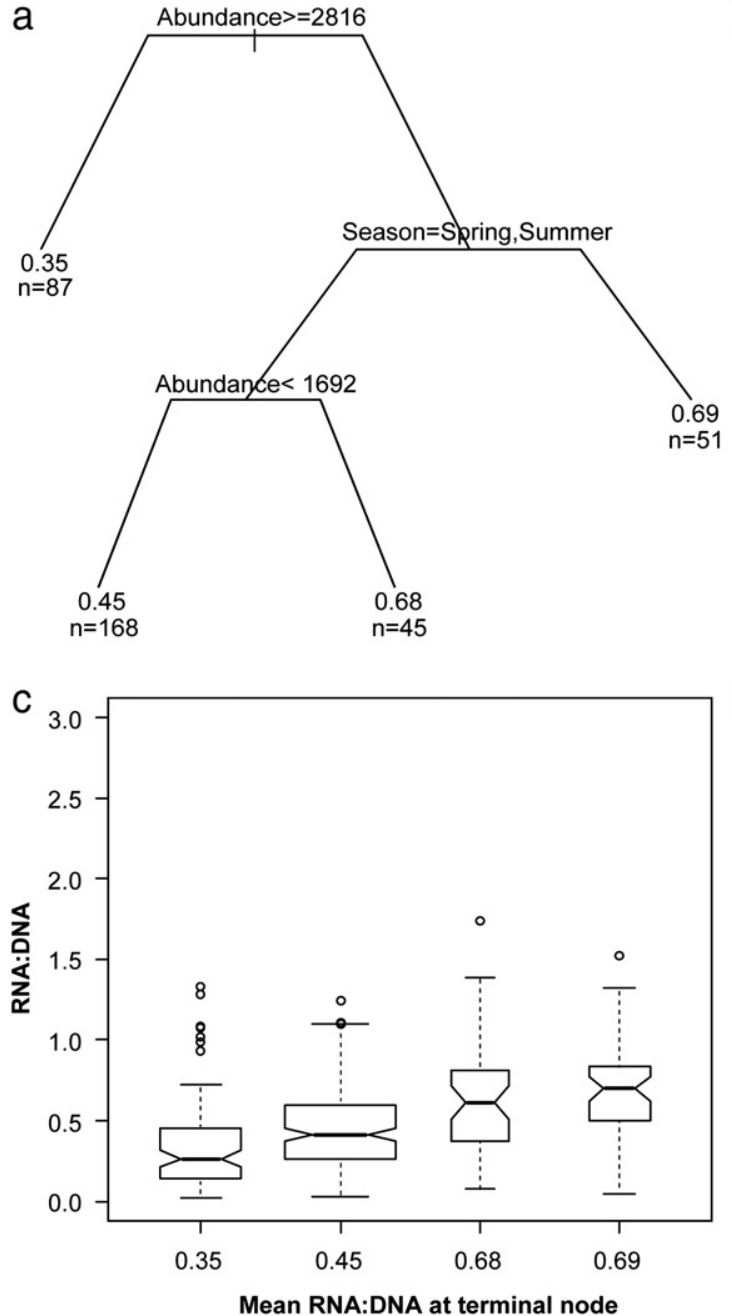

b
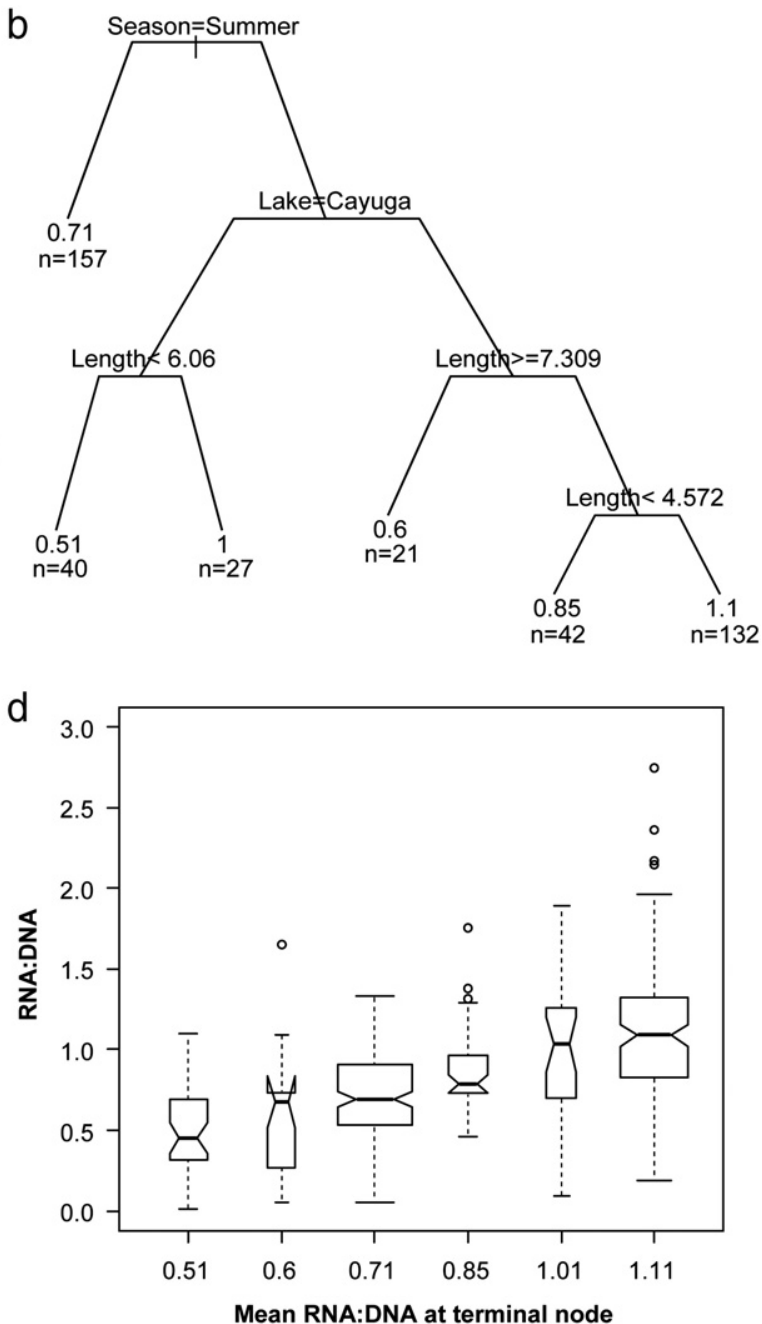

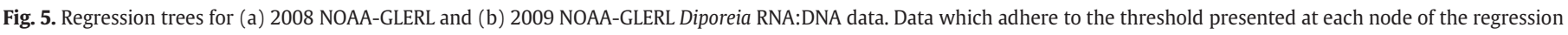

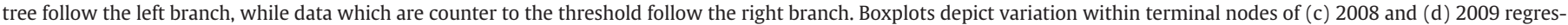

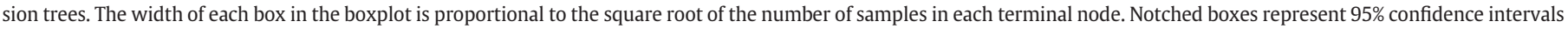
about the median.

condition whereby survivors are released from density dependent processes (i.e., an increase in food availability) or 2) low condition because Diporeia are responding to an unknown environmental stressor affecting both population density and individual condition.

Depth was selected as an initial split in multiple trees, suggesting that depth has a relatively moderate influence on Diporeia condition. CART analyses indicate marginally lower Diporeia condition at deeper sites. Diporeia in the Great Lakes appear to prefer slope regions over profundal regions (Evans et al., 1990; Auer et al., 2009), as growth, condition and survival may be low in deep, unproductive zones. Moreover, the potential dreissenid induced shunting of primary productivity to nearshore areas may have reduced detrital inputs to profundal areas (Guiguer and Barton, 2002; Hecky et al., 2004), and this could also reduce Diporeia condition. The combination of these factors suggests that Diporeia at deep sites exhibit lower condition.

The lake in which Diporeia were collected was selected as an intermediate splitting variable in determining Diporeia condition, suggesting that although Diporeia condition may vary somewhat among lakes, variation among individual sites is greater. This is not surprising, considering the large scale, spatially dynamic processes that occur within each Great Lake (e.g., upwelling events, depositional zones) which can lead to dramatically different environmental conditions across a single lake (Boyce et al., 1989; Croley, 1992; Jude and
Leach, 1999; Nalepa et al., 2006b; Watkins et al., 2007). Several studies have attributed condition of invertebrates to similar dynamics (Gardner et al., 1985; Hill et al., 1992; Cavaletto et al., 1996; Nalepa et al., 2000), also suggesting that Diporeia R/D characteristics are more heavily influenced by site specific conditions rather than lake wide characteristics. It is also noteworthy that we observed no large across-lake differences in Diporeia R/D when comparing lakes where Diporeia populations are declining versus stable (i.e., Lakes Michigan, Huron and Ontario v. Lakes Superior and Cayuga).

We did not find any associations between the presence of dreissenids and Diporeia R/D at individual sites. We simply evaluated the potential effect of presence or absence of dreissenids at a particular location, which may not have captured complex or remote interactions between the invertebrates. For instance, Watkins et al. (2007) suggested nearshore dreissenid activities remotely affect profundal Diporeia populations in Lake Ontario through competitive grazing and deposition of pseudofeces. Guiguer and Barton (2002) proposed that littoral epilithic algae plays an important role in the diets of offshore Diporeia, and thus, interception of this food source by dreissenids upslope could affect offshore Diporeia condition. Nonetheless, if dreissenids negatively impact Diporeia, this finding underscores the complex interactions between the two invertebrates (Dermott, 2001; Nalepa et al., 2006b; Watkins et al., 2007). 


\section{Conclusion}

To explore spatial and temporal variation of Diporeia condition, we quantified nucleic acid indices and integrated measures from experiments and in situ collected Diporeia. Experimental results seem to suggest that nucleic acids are useful for indexing Diporeia condition in the laboratory, as found by Kainz et al. (2010). However, we observed a high degree of spatial and temporal R/D variation from in situ Diporeia and multiple CART analyses did not explain a large amount of this variation. Nonetheless, season, Diporeia length, abundance and depth contributed toward explaining a low amount of Diporeia R/D variation, while interestingly, the presence of dreissenids did not. The lack of strong relationships between environmental variables and Diporeia R/D is consistent with several other studies which have failed to find a consistent mechanism underlying declines of Diporeia in the Great Lakes.

The results of this study appear to have conflicting evidence on the usefulness of R/D to accurately index Diporeia condition. On one hand, experimental results that attempted to simulate hypolimnetic conditions demonstrate significant effects of starvation on R/D levels over intermediate time scales (14-30 days), and nucleic acid ratios seemingly respond to severe short term stresses such as handling and transport. Kainz et al. (2010) also demonstrated that R/D ratios of Diporeia respond to dietary content over 30 days. The independently evaluated results presented here, in conjunction with Kainz et al. (2010), indicate that Diporeia R/D can be influenced by controlled environments at intermediate time scales. In contrast, R/D for in situ collected Diporeia were highly variable both within and across sample sites, lacked strong associations with environmental conditions and comparisons between experimental and in situ Diporeia R/D were not strikingly different. It is plausible that the degree of ambient variability experienced by Diporeia at a specific location is far greater than the environmental variability observed by Diporeia across different locations within our study lakes. That is, since Diporeia inhabit cold, stable regions, their R/D values in the Great Lakes may not vary dramatically between the sites sampled. Moreover, intermittent feeding and ontogenic variation such as molting stage of Diporeia could lead to high individual variability in Diporeia R/D which could further confound ability to detect across site patterns (Quigley, 1988; Evans et al., 1990; Gorokhova and Kyle, 2002; Schlechtriem et al., 2008). Overall, it is known that R/D ratios can be successfully used to measure the condition of a variety of organisms, but the ability of R/D ratios to accurately index Diporeia condition for in situ collected specimens is poorly understood. Investigations into Diporeia physiology and how Diporeia nucleic acids are influenced by environmental conditions could potentially improve our understanding as to why spatial patterns in Diporeia R/D were highly variable. It remains an open question why Diporeia have declined precipitously in many areas of the Great Lakes. Diporeia R/D seemingly respond to feeding conditions (Kainz et al., 2010 and this study), but while Diporeia R/ $\mathrm{D}$ was weakly related to depth, there were no clear, consistent patterns between Diporeia R/D, season and dreissenid presence. Similarly, Nalepa et al. (2006a) found that Diporeia lipid levels increased even though the population was decreasing at a southern Lake Michigan site. Thus, we suggest that future studies could further evaluate Diporeia physiology and nucleic acid responses to environmental conditions since little is known about these phenomena. Moreover, Nalepa et al. (2006a) observed a lack of recruitment by young of year Diporeia as they declined from a Lake Michigan site. We were unable to quantify young of year Diporeia condition due to the lack of Diporeia young of year in our samples. Perhaps, young of year Diporeia were absent from our study sites or small enough to pass through a $500 \mu \mathrm{m}$ sieve and be unnoticed by the naked eye (Johnson, 1988). Nonetheless, we suggest that future research should target early ontogenic stages to hopefully further elucidate mechanisms underlying the decline of this important Great Lakes amphipod.
Supplementary materials related to this article can be found online at doi:10.1016/j.jglr.2012.01.007.

\section{Acknowledgments}

We gratefully acknowledge the contributions of the captains and crews of the R/V Lake Guardian and R/V Laurentian for assisting with Diporeia collections. We would also like to thank Jim Watkins for assisting with Diporeia collections in Cayuga Lake, and Dave Fanslow for leading collections in Batchawanna Bay, Lake Superior. Without the help of these individuals, this project would not have been possible. Equally, we would like to extend our grateful appreciation to numerous persons that have assisted us during this project, including: Carolyn Foley, Suman Maity, Steve Hensler, Greg Jacobs, Julie Mida, Kyung Seo Park, Anna Varian, S. Grace McCalla, Hui-Yu Wang and several lab technicians. Funding for this project was provided by the Great Lakes Fishery Trust (Grant\# 2008.886). This is NOAA-GLERL contribution 1619.

\section{References}

Abramoff, M.D., Magelhaes, P.J., Ram, S.J., 2004. Image processing with image. J. Biophotonics Int. 11, 36-42.

Auer, N.A., Cannon, B.A., Auer, M.T., 2009. Life history, distribution, and production of Diporeia near the Keweenaw Peninsula Lake Superior. J. Great Lakes Res. 35 579-590.

Berdalet, E., Roldan, C., Olivar, M.P., Lysnes, K., 2005. Quantifying RNA and DNA in planktonic organisms with SYBR Green II and nucleases. Part A. Optimisation of the assay. Sci. Mar. 69, 1-16.

Boyce, F.M., Donelan, M.A., Hamblin, P.F., Murthy, C.R., Simons, T.J., 1989. Thermal structure and circulation in the Great Lakes. Atmosphere-Ocean 27, 607-642.

Breiman, L., Friedman, J.H., Olshen, R.A., Stone, C.J., 1984. Classification and Regression Trees. Wadsworth International Group, Belmont, CA.

Buckley, L.J., 1984. RNA:DNA ratio - an index of larval fish growth in the sea. Mar. Biol. 80, 291-298.

Buckley, L.J., Turner, S.I., Halavik, T.A., Smigielski, A.S., Drew, S.M., Laurence, G.C., 1984 Effects of temperature and food availability on growth, survival, and RNA:DNA ratio of larval sand lance (Ammodytes americanus). Mar. Ecol. Prog. Ser. 15, 91-97.

Bulow, F.J., 1987. RNA-DNA ratios as indicators of growth in fish. In: Summerfelt, R.C., Hall, G.E. (Eds.), The Age and Growth of Fish. Iowa State University Press, Ames, Iowa, pp. 45-64.

Caldarone, E.M., Clemmesen, C.M., Berdalet, E., Miller, T.J., Folkvord, A., Holt, G.J., Olivar M.P., Suthers, I.M., 2006. Intercalibration of four spectrofluorometric protocols for measuring RNA/DNA ratios in larval and juvenile fish. Limnol. Oceanogr. Methods 4, 153-163.

Cavaletto, J.F., Nalepa, T.F., Dermott, R., Gardner, W.S., Quigley, M.A., Lang, G.A., 1996 Seasonal variation of lipid composition weight, and length in juvenile Diporeia spp. (Amphipoda) from Lakes Michigan and Ontario. Can. J. Fish. Aquat. Sci. 53, 2044-2051.

Chicharo, L.M.Z., Chicharo, M., 1995. The DNA/RNA ratio as a useful indicator of the nutritional condition in juveniles of Ruditapes decussatus. Sci. Mar. 59, 95-101.

Clemmesen, C.M., 1994. The effect of food availability, age or size on the RNA/DNA ratio of individually measured herring larvae: laboratory calibration. Mar. Biol. 118 377-382.

Croley, T.E., 1992. Long-term heat storage in the Great Lakes. Water Resour. Res. 28, 69-81.

Dahlberg, A.E., 1989. The functional role of ribosomal RNA in protein synthesis. Cell 57, 525-529.

De'ath, G., Fabricius, K.E., 2000. Classification and regression trees: a powerful yet simple technique for ecological data analysis. Ecology 81, 3178-3192.

Dermott, R., 1995. Production and growth efficiency of two burrowing invertebrates, Hexagenia limbata and Diporeia hoyi, in Batchawana Bay, Lake Superior. Can. Data Rep. Fish. Aquat. Sci. 2034.

Dermott, R., 2001. Sudden disappearance of the amphipod Diporeia from eastern Lake Ontario, 1993-1995. J. Great Lakes Res. 27, 423-433.

Dermott, R., Corning, K., 1988. Seasonal ingestion rates of Pontoporeia hoyi (Amphipoda) in Lake Ontario. Can. J. Fish. Aquat. Sci. 45, 1886-1895.

Dermott, R., Kerec, D., 1997. Changes to the deepwater benthos of eastern Lake Erie since the invasion of Dreissena: 1979-1993. Can. J. Fish. Aquat. Sci. 54 922-930.

Dermott, R., Bonnell, R., Jarvis, P., 2005a. Population status of the amphipod Diporeia in eastern North American lakes with or without Dreissena. Verh. Internat. Verein Limnol. 29, 880-886.

Dermott, R., Munawar, M., Bonnell, R., Carou, S., Niblock, H., Nalepa, T.F., Messick, G., 2005b. Preliminary investigations for causes of the disappearance of Diporeia spp. from Lake Ontario. In: Mohr, L.C., Nalepa, T.F. (Eds.), Proceedings of a workshop on the dynamics of lake whitefish (Coregonus clupeaformis) and the amphipod Diporeia spp. in the Great Lakes: Great Lakes Fish. Comm. Tech. Rep, 66, pp. 203-232. 
Development Core Team, R., 2009. R: A Language and Environment for Statistical Computing. R Foundation for Statistical Computing, Vienna, Austria.

Evans, M.S., Quigley, M.A., Wojcik, J.A., 1990. Comparative ecology of Pontoporeia hoyi populations in southern Lake Michigan - the profundal region versus the slope and shelf regions. J. Great Lakes Res. 16, 27-40.

Faraway, J.J., 2006. Trees. Extending the Linear Model with R: Generalized Linear, Mixed Effects and Nonparametric Regression Models. Chapman and Hall, Boca Raton, Florida, pp. 253-268.

Fitzgerald, S.A., Gardner, W.S., 1993. An algal carbon budget for pelagic-benthic coupling in Lake Michigan. Limnol. Oceanogr. 38, 547-560.

Flint, R.W., 1986. Hypothesized carbon flow through the deep water Lake Ontario food web. J. Great Lakes Res. 12, 344-354.

Foley, C.J., Ryan, D.J., Hook, T.O., 2010. Length reduction of larval yellow perch and freshwater amphipods in RNAlater solution. N. Am. J. Fish. Manage. 30, 1143-1148

Gardner, W.S., Nalepa, T.F., Frez, W.A., Cichocki, E.A., Landrum, P.F., 1985. Seasonal patterns in lipid content of Lake Michigan macroinvertebrates. Can. J. Fish. Aquat. Sci. $42,1827-1832$.

Gauvin, J.M., Gardener, W.S., Quigley, M.A., 1989. Effects of food removal on nutrient release rates and lipid content of Lake Michigan Pontoporeia hoyi. Can. J. Fish. Aquat. Sci. 46, 1125-1130

Gorokhova, E., 2003. Relationships between nucleic acid levels and egg production rates in Acartia bifilosa: implications for growth assessment of copepods in situ. Mar. Ecol. Prog. Ser. 262, 163-172.

Gorokhova, E., 2005. Effects of preservation and storage of microcrustaceans in RNAlater on RNA and DNA degradation. Limnol. Oceanogr. Methods 3, 143-148.

Gorokhova, E., Kyle, M., 2002. Analysis of nucleic acids in Daphnia: development of methods and ontogenetic variations in RNA-DNA content. J. Plankton Res. 24, 511-522.

Grigorovich, I.A., Korniushin, A.V., Gray, D.K., Duggan, I.C., Colautti, R.I., MacIsaac, H.J., 2003. Lake Superior: an invasion coldspot? Hydrobiologia 499, 191-210.

Grigorovich, I.A., Kelly, J.R., Darling, J.A., West, C.W., 2008. The quagga mussel invades the Lake Superior basin. J. Great Lakes Res. 34, 342-350.

Guiguer, K.R.R.A., Barton, D.R., 2002. The trophic role of Diporeia (Amphipoda) in Colpoys Bay (Georgian Bay) benthic food web: a stable isotope approach. J. Great Lakes Res. 28, 228-239.

Hecky, R.E., Smith, R.E.H., Barton, D.R., Guildford, S.J., Taylor, W.D., Charlton, M.N., Howell, T. 2004. The nearshore phosphorus shunt: a consequence of ecosystem engineering by dreissenids in the Laurentian Great Lakes. Can. J. Fish. Aquat. Sci. 61, 1285-1293.

Hill, C., Quigley, M.A., Cavaletto, J.F., Gordon, W., 1992. Seasonal changes in lipid content and composition in the benthic amphipods Monoporeia affinis and Pontoporeia femorata. Limnol. Oceanogr. 37, 1280-1289.

Holmborn, T., Dahlgren, K., Holeton, C., Hogfors, H., Gorokhova, E., 2009. Biochemical proxies for growth and metabolism in Acartia bifilosa (Copepoda, Calanoida). Limnology and Oceanography: Methods 7, 785-794.

Hondorp, D.W., Pothoven, S.A., Brandt, S.B., 2005. Influence of Diporeia density on diet composition, relative abundance, and energy density of planktivorous fishes in southeast Lake Michigan. Trans. Am. Fish. Soc. 134, 588-601.

Höök, T.O., Gorokhova, E., Hansson, S., 2008. RNA:DNA ratios of Baltic Sea herring larvae and copepods in embayment and open sea habitats. Estuar. Coast. Shelf Sci. 76, 29-35.

Hoyle, J.A., 2005. Status of lake whitefish (Coregonus clupeaformis) in Lake Ontario and the response to the disappearance of Diporeia spp. In: Mohr, L.C., Nalepa, T.F. (Eds.) Proceedings of a workshop on the dynamics of lake whitefish (Coregonus clupeaformis) and the amphipod Diporeia spp. in the Great Lakes: Great Lakes Fish. Comm. Tech. Rep., 66, pp. 47-66.

Johannsson, O.E., Bowen, K.L., Wood, C.M., Smith, R.W., Chu, C., Rudstam, L.G. Boscarino, B., 2008. Relating nucleic acid and protein indices to growth in Mysis relicta: ration, cycling temperature, and metabolism. Aquat. Biol. 4, 33-46.

Johnson, M.G., 1988. Production by the amphipod Pontoporeia hoyi in South Bay, Lake Huron. Can. J. Fish. Aquat. Sci. 45, 617-624.

Johnson, M.L., Kim, S.H., Emche, S.D., 2003. Storage effects on genomic DNA in rolled and mature coca leaves. Biotechniques 35, 310-316.

Jude, D.J., Leach, J., 1999. Great Lakes Fisheries. In: Kohler, C.C., Hubert, W.A. (Eds.), Inland Fisheries Management in North America. American Fisheries Society, Bethesda, Maryland, pp. 623-664.

Kainz, M.J., Johannsson, O.E., Arts, M.T., 2010. Diet effects on lipid composition, somatic growth potential, and survival of the benthic amphipod Diporeia spp. J. Great Lakes Res. 36, 351-356.

Lamon, E.C., Stow, C.A., 1999. Sources of variability in microcontaminant data for Lake Michigan salmonids: statistical models and implications for trend detection. Can. J. Fish. Aquat. Sci. 56, 71-85.

MacLean, S.A., Caldarone, E.M., Onge-Burns, J.M.S., 2008. Estimating recent growth rates of Atlantic salmon smolts using RNA-DNA ratios from nonlethally sampled tissues. Trans. Am. Fish. Soc. 137, 1279-1284.
Meyers, P.A., Eadie, B.J., 1993. Sources, degradation and recycling of organic matter associated with sinking particles in Lake Michigan. Org. Geochem. 20, 47-56.

Nalepa, T.F., Hartson, D.J., Buchanan, J., Cavaletto, J.F., Lang, G.A., Lozano, S.J., 2000. Spatial variation in density, mean size and physiological condition of the Holarctic amphipod Diporeia spp. in Lake Michigan. Freshw. Biol. 43, 107-119.

Nalepa, T.F., Fanslow, D.L., A.J.F. Ill, Lang, G.A., Eadie, B.J., Quigley, M.A., 2006a. Continued disappearance of the benthic amphipod Diporeia spp. in Lake Michigan: is there evidence for food limitation? Can. J. Fish. Aquat. Sci. 63, 872-890.

Nalepa, T.F., Rockwell, D.C., Schloesser, D.W., 2006b. Disappearance of the amphipod Diporeia spp. in the Great Lakes: workshop summary, discussion, and recommendations. NOAA Tech. Rep. ERL GLERL - 126. Ann Arbor, MI.

Nalepa, T.F., Fanslow, D.L., Pothoven, S.A., Foley, A.J., Lang, G.A., 2007. Long term trends in benthic macroinvertebrate populations in Lake Huron over the past four decades. J. Great Lakes Res. 33, 421-436.

Nalepa, T.F., Fanslow, D.L, Lang G.A. 2009. Transformation of the offshore benthic community in Lake Michigan: recent shift from the native amphipod Diporeia spp. to the invasive mussel Dreissena rostriformis bugensis. Freshw. Biol. 54, 466-479.

Pothoven, S.A., 2005. Changes in lake whitefish diet in Lake Michigan, 1998-2001. In: Mohr, L.C., Nalepa, T.F. (Eds.), Proceedings of a workshop on the dynamics of lake whitefish (Coregonus clupeaformis) and the amphipod Diporeia spp. in the Great Lakes: Great Lakes Fish. Comm. Tech. Rep., 66, pp. 127-140.

Pothoven, S.A., Nalepa, T.F, Schneeberger, P. Brandt, S.B., 2001. Changes in diet and body condition of lake whitefish in southern Lake Michigan associated with changes in benthos. N. Am. J. Fish. Manage. 21, 876-883.

Qian, S.S., 2010. Classification and regression tree. Environmental and Ecological Statistics with R. Chapman and Hall, Boca Raton: Florida, pp. 217-247.

Quigley, M.A., 1988. Gut fullness of the deposit-feeding amphipod, Pontoporeia hoyi, in southeastern Lake Michigan. J. Great Lakes Res. 14, 178-187.

Quigley, M.A., Vanderploeg, H.A., 1991. Ingestion of live filamentous diatoms by the Great Lakes amphipod, Diporeia sp.: a case study of the limited value of gut contents analysis. Hydrobiologia 223, 141-148.

Rejwan, C., Collins, N.C., Brunner, L.J., Shuter, B.J., Ridgway, M.S., 1999. Tree regression analysis on the nesting habitat of smallmouth bass. Ecology 80, 341-348.

Ryan, D.J. 2010. Spatial variation in condition and consumptive demand of Diporeia spp. in the Great Lakes region. M. Sc. Thesis, Purdue University, West Lafayette.

Scharold, J.V., Lozano, S.J., Corry, T.D., 2004. Status of the amphipod Diporeia spp. in Lake Superior, 1994-2000. J. Great Lakes Res. 30, 360-368.

Schlechtriem, C., Johannsson, O.E., Bowen, K.L., Smith, R.W., Arts, M.T., 2008. Effect of fasting under different temperature conditions on nucleic acid ratios in the opossum shrimp Mysis relicta: a calibration approach. J. Great Lakes Res. 34, 461-471.

Speekmann, C.L., Nunez, B.S., Buskey, E.J., 2007. Measuring RNA:DNA ratios in individual Acartia tonsa (Copepoda). Mar. Biol. 151, 759-766.

Sundelin, B., Rosa, R., Wiklund, A.E., 2008. Reproduction disorders in the benthic amphipod Monoporeia affinis: an effect of low food resources. Aquat. Biol. 2, 179-190.

Sutcliffe Jr., W.H., 1965. Growth estimates from ribonucleic acid content in some small organisms. Limnol. Oceanogr. 10, 253-258.

Therneau, T.M., Atkinson, B., Ripley, B., 2010. Recursive partitioning and regression trees. R Statistical Package, Version 3, pp. 1-46.

Vrede, T., Persson, J., Aronsen, G., 2002. The influence of food quality (P:C ratio) on RNA:DNA ratio and somatic growth rate of Daphnia. Limnol. Oceanogr. 47, 487-494

Wagner, M., Durbin, E., Buckley, L., 1998. RNA:DNA ratios as indicators of nutritional condition in the copepod Calanus finmarchicus. Mar. Ecol. Prog. Ser 162, 173-181.

Wagner, M.M., Campbell, R.G., Boudreau, C.A., Durbin, E.G., 2001. Nucleic acids and growth of Calanus finmarchicus in the laboratory under different food and temperature conditions. Mar. Ecol. Prog. Ser. 221, 185-197.

Wang, H.Y., Hook, T.O., Ebener, M.P., Mohr, L.C., Schneeberger, P.J., 2008. Spatial and temporal variation of maturation schedules of lake whitefish (Coregonus clupeaformis) in the Great Lakes. Can. J. Fish. Aquat. Sci. 65, 2157-2169.

Watkins, J.M., Dermott, R., Lozano, S.J., Mills, E.L., Rudstam, L.G., Scharold, J.V., 2007. Evidence for remote effects of dreissenid mussels on the amphipod Diporeia: analysis of Lake Ontario benthic surveys, 1972-2003. J. Great Lakes Res. 33, 642-657.

Winnell, M.H., White, D.S., 1984. Ecology of shallow and deep water populations of Pontoporeia hoyi (Smith) (Amphipoda) in Lake Michigan. Freshw. Invertebr. Biol. 3, 118-1318.

Wright, D.A., Hetzel, E.W., 1985. Use of RNA:DNA ratios as an indicator of nutritional stress in the American oyster Crassostrea virginica. Mar. Ecol. Prog. Ser. 25, 199-206.

Wu, R.S.S., Or, Y.Y., 2005. Bioenergetics, growth and reproduction of amphipods are affected by moderately low oxygen regimes. Mar. Ecol. Prog. Ser. 297, 215-223. 